\title{
Molecular diversity among domestic guinea-pigs (Cavia porcellus) and their close phylogenetic relationship with the Andean wild species Cavia tschudii
}

\author{
Diversidad molecular entre cuyes domésticos (Cavia porcellus) y su relación \\ filogenética cercana con la especie silvestre andina Cavia tschudii
}

\author{
ÁNGEL E. SPOTORNO ${ }^{1}$, JOHN P. VALLADARES ${ }^{1}$, JUAN C. MARÍN ${ }^{1} \&$ HORACIO ZEBALLOS $^{2}$ \\ ${ }^{1}$ Laboratorio de Genómica Evolutiva de Mamíferos, ICBM, Facultad de Medicina, Universidad de Chile, Casilla 70061, \\ Santiago 7, Chile; e- mail: aspotorn@med.uchile.cl \\ ${ }^{2}$ Center for Avanced Studies in Ecology \& Biodiversity, Departamento de Ecología, \\ Pontificia Universidad Católica de Chile
}

\begin{abstract}
To investigate the origin and diversity of domestic guinea-pigs Cavia porcellus (Linnaeus, 1758; Rodentia, Caviidae), we sequenced the mitochondrial cytochrome $b$ gene of 12 domestic and 10 wild specimens from six species, including the two presumed as ancestral to the domestic one: Cavia tschudii and Cavia aperea. All maximum parsimony and maximum likelihood analyses grouped $C$. porcellus with $C$. tschudii (mean K2P distance $=3.2 \%)$; best trees had 609 steps $(\mathrm{CI}=0.796$; Bremer support Index $(\mathrm{SI})=28)$, and a $-\mathrm{Ln}=$ 4419.52, with $100 \%$ and $97 \%$ bootstrap support respectively. This clade, supported by three substitutions and $96 \%$ bootstrap, is also obtained in the cladistic analysis of corresponding amino acids. When the $C$. aperea node was forced to join $C$. porcellus, these trees were consistently longer, less likely and robust, and with less defining characters than the optimal one. All C. porcellus sequences also clustered in a node defined by 15 substitutions. The sub-node containing animals from city markets, pet shops and laboratories was characterized by four substitutions (one non-silent, SI $=7$, and $91 \%$ bootstrap). Some South American $C$. porcellus, called "criollos" (creoles) by local breeders, were more diverse. Probably, a particular clade from southern Peru and Chile may represent a pre-Columbian lineage. Mean K2P distance between C. tschudii and C. aperea was rather large, $7.7 \%$. Cavia appeared as a robust node (100\% bootstrap). These results indicate that $C$. tschudii is the species most closely related to C. porcellus.
\end{abstract}

Key words: Andes, Caviidae, cytochrome b, domestication, guinea pig, molecular phylogeny.

\section{RESUMEN}

Para investigar el origen y la divergencia de los cuyes domésticos Cavia porcellus (Linnaeus, 1758; Rodentia, Caviidae), secuenciamos el gen mitocondrial para citocromo b de 12 especímenes domésticos y 10 silvestres de seis especies, incluyendo las dos que se presumen como ancestro de la doméstica: $C$. tschudii y $C$. aperea. Todos los análisis de máxima parsimonia y máxima verosimilitud agruparon a $C$. porcellus con $C$. tschudii (promedio de distancias $\mathrm{K} 2 \mathrm{P}=3,2 \%$ ); los mejores árboles tenían 609 pasos $(\mathrm{CI}=0,796$; Índice de Apoyo de Bremer $(\mathrm{SI})=28)$, y un $-\mathrm{Ln}=4.419,52$; con apoyos de remuestreo de $100 \%$ y $97 \%$ respectivamente. Dicho clado también apareció en el análisis cladístico de los aminoácidos correspondientes, apoyado por tres sustituciones y $96 \%$ remuestreo. Cuando el nodo de $C$. aperea fue forzado a unirse al de $C$. porcellus, estos árboles fueron consistentemente más largos, menos probables y robustos, y con menos caracteres definitorios que el óptimo. Todas las secuencias de C. porcellus se agruparon también en un nodo definido por 15 sustituciones. El subnodo con animales de mercados de ciudad, tiendas de mascota y laboratorios se caracterizó por cuatro sustituciones (una no silenciosa, SI $=7$ y $91 \%$ remuestreo). Los C. porcellus sudamericanos, llamados "criollos" por los criadores locales, son más diversos. Probablemente, un clado del sur del Perú y Chile representa un linaje precolombino. La distancia K2P promedio entre $C$. tschudii y aperea fué más bien grande, $7,7 \%$. Cavia apareció como un nodo robusto (100\% remuestreo). Estos resultados indican que $C$. tschudii es la especie más cercanamente relacionada a $C$. porcellus.

Palabras clave: Andes, Caviidae, citocromo b, domesticación, cuy, filogenia molecular. 


\section{INTRODUCTION}

Guinea pigs Cavia porcellus (Linnaeus, 1758; Rodentia, Caviidae) have been well-known domestic pets since their introduction to Europe in the sixteenth century, from undocumented sources (Woods 1993); they became the prototype of laboratory models through the nineteenth century (Wagner \& Manning 1976). South American breeds still are today important mammals in folk medicine, native religion, and are a popular food in the Andean countries (Spotorno 1982 ${ }^{1}$, Morales 1995). They were domesticated in pre-Columbian times by Amerindian peoples, in the only mammalian domestication center of the New World (Wing 1986). Given the almost continuous presence of guinea pig mummies in pre-Hispanic human burials (Sandweiss \& Wing 1997), present South American populations are probably the descendants of pre-Columbian lineages. Whether Andean and laboratory/pet breeds are genetically distinct is uncertain (Spotorno 1982) ${ }^{1}$.

All domestic guinea pigs are usually identified within the nominal species Cavia porcellus (Woods 1993), although a few authors call them Cavia aperea f. porcellus (i.e., Huckinghaus 1961, Sachser 1998). The latter usage is based on the fact that domestic guinea pigs crossed with Cavia aperea gave fertile hybrids (Pictet \& Ferrero 1951, Sachser 1998), suggesting that domestic guinea pigs are derived from such wild species. The taxonomic issue was recently settled by the International Commission on Zoological Nomenclature (Nomenclature 2003), conserving the scientific names Cavia aperea (Erxleben, 1777) for one wild species, and Cavia porcellus (Linnaeus, 1758) for domestic guinea pigs. However, the precise origin and derivation of domestic guinea pigs is unknown (Anderson 1997, Clutton-Brock 1999). Specifically, in addition to Cavia aperea from Argentina, Bolivia, Uruguay, Colombia and Brazil (Cabrera 1953), two other wild species have been postulated as the ancestor of domestic guinea pigs: $C$. tschudii from Peru and Chile (Weir 1974), which also gave fertile hybrids both sexes when crossed with $C$. porcellus (Castle \& Wright 1916), and C. fulgida from Brazil (Weir 1974). The latter alternative is improbable, since hybrid males produced from $C$.

\footnotetext{
${ }^{1}$ SPOTORNO AE (1982) Conservation of South American mammals. In: Mares M \& HH Genoways (eds) Biology of South American mammals: 527-528. Symposia of Pymatuning Laboratory of Ecology, University of Pittsburgh, Pittsburgh, USA.
}

porcellus x C. fulgida crosses were infertile (Detlefsen 1914).

To estimate the molecular phylogeny among domestic guinea pigs and to test for possible close relationships with one of the wild species, we analyze here the cytochrome $b$ gene sequence of 14 domestic specimens from South American popular markets, rural houses or small localities, and pet shops in Colombia, Peru, Chile and Argentina. They are compared with those obtained from 17 wild specimens of six different Caviidae species from six South American countries. We include samples from the two most likely candidate species, to infer the probable wild counterpart of domestic guinea pigs. Although molecular relationships within Caviidae (Needbal et al. 1994) and comparisons with morphological and ecological correlates have been recently assessed using other molecular markers (Rowe \& Honeycutt 2002), these studies did not include those two species simultaneously, nor any sample of present-day South American domestic guinea pigs. We document here their molecular identity, the molecular divergence among them, and their phylogenetic relationships.

\section{MATERIAL AND METHODS}

\section{Specimens}

Wild animals were collected in the field and ear or skin samples were taken in some specimens. Skulls and skins, whenever available, were identified with the key of Cabrera (1953), and prepared as voucher specimens; most were deposited in the collection of the Laboratorio de Genómica Evolutiva, Instituto de Ciencias Biomédicas, Facultad de Medicina, Universidad de Chile, Santiago, Chile (acronym LCM). Other tissue samples were obtained from: Museo Nacional de Historia Natural (MNHN), Santiago, Chile; Museum of Southwestern Biology (MSB), New Mexico, United States; Colección de Tejidos del Laboratorio de Evolución (EV), Facultad de Ciencias, Universidad de La República, Montevideo, Uruguay, and Museo de Historia Natural de la Universidad Nacional de San Agustín de Arequipa, Peru (MUSA).

Taxonomic names, following Woods (1993), original localities of examined specimens, source (LCM or other collection numbers in parenthesis), and GenBank accession numbers (GB) of sequences are listed in Table 1.

DNA was extracted from liver samples fixed in $75^{\circ}$ alcohol using sodium dodecyl sulfate-proteinase $\mathrm{KNaCl}$ extraction and alcohol 


\section{TABLE 1}

Specimens examined, localities of origin, source (collection and specimen numbers, see Material and Methods), and GenBank accession numbers

Especímenes examinados, localidades de origen, fuente (colección y número en colección, ver "Material and Methods"), y números de acceso en GenBank

\begin{tabular}{|c|c|c|c|}
\hline Species & Locality & Source & GenBank accession number \\
\hline Dolichotis patagonum & Argentina: Santa Cruz & LCM 3077 & AY382787 $1140 \mathrm{bp}$ \\
\hline Galea musteloides & Perú: Puno, Desaguadero & LCM 2494 & AY466603 1125 bp \\
\hline Galea musteloides & Perú: Puno, Sillustani & LCM 2496 & AY466604 1125 bp \\
\hline Galea musteloides & Bolivia: La Paz & MSB 30655 & AY466605 $1125 \mathrm{bp}$ \\
\hline Galea musteloides & Bolivia: Tarija & MSB 14687 & AF491753 645 bp \\
\hline Galea musteloides & Argentina: Lujan & MHHN 1017 & AF491752 678 bp \\
\hline Microcavia niata & Chile: Colchane & LCM 2500 & AY382788 $1140 \mathrm{bp}$ \\
\hline Microcavia niata & Chile: Colchane & LCM 2501 & AY382789 1140 bp \\
\hline Microcavia niata & Chile: Colchane & MNHN 1013 & AF491751 678 bp \\
\hline Microcavia australis & Argentina: Río Desaguadero & MNHN 1465 & AF491750 678 bp \\
\hline Cavia aperea & Bolivia: Santa Cruz & MSB 22547 & AY382790 $1140 \mathrm{bp}$ \\
\hline Cavia aperea & Paraguay: Concepción & MSB 27546 & AY382791 $1140 \mathrm{bp}$ \\
\hline Cavia aperea & Bolivia: Santa Cruz & MSB 22547 & AF491748 678 bp \\
\hline Cavia aperea & Uruguay: Maldonado & EV 1008 & AF491749 678 bp \\
\hline Cavia tschudii & Chile: Arica, Lluta & LCM $205 f$ & AF491292 $545 \mathrm{bp}$ \\
\hline Cavia tschudii & Chile: Arica, Lluta & MNHN 1019 & AF491747 642 bp \\
\hline Cavia tschudii & Perú: Cuzco & LCM 2562 & AY382792 $1140 \mathrm{bp}$ \\
\hline Cavia tschudii & Perú: Puno & LCM 2495 & AY245099 1140 bp \\
\hline Cavia porcellus & Laboratory breed & GB GenBank & NC 0884.15825988 \\
\hline Cavia porcellus & Argentina: San Luis: pet shop & LCM D2441 & AY228362 1140 bp \\
\hline Cavia porcellus & Colombia: Palmira market & LCM D2347 & AF490405 1140 bp \\
\hline Cavia porcellus & Perú: Piura city market & LCM D2410 & AY245094 1140 bp \\
\hline Cavia porcellus & Perú: Trujillo city market & LCM D2414 & AY245095 $1140 \mathrm{bp}$ \\
\hline Cavia porcellus & Chile: Arica, popular agromarket & LCM d 2463 & AY382793 1140 bp \\
\hline Cavia porcellus & Chile: Talabre rural house & LCM d 1845 & AF491745 678 bp \\
\hline Cavia porcellus & Chile: San Pedro Atacama house & LCM d 2548 & AY228361 $1140 \mathrm{bp}$ \\
\hline Cavia porcellus & Perú: Arequipa popular market & LCM d 2498 & AY247008 1140 bp \\
\hline Cavia porcellus & Perú: Cajamarca popular market & LCM d 2412 & AY245096 1140 bp \\
\hline Cavia porcellus & Perú: Cusco popular market & LCM d 2416 & AY245097 1140 bp \\
\hline Cavia porcellus & Perú: Tacna popular market & LCM d 2308 & AY228363 1140 bp \\
\hline Cavia porcellus & Perú: Arequipa popular market & LCM d 2461 & AF490404 490 bp \\
\hline Cavia porcellus & Perú: Puno popular market & LCM d 2497 & AY245098 1140 bp \\
\hline
\end{tabular}

precipitation (Maniatis et al. 1992). The mitochondrial cytochrome $b$ gene was amplified via the polymerase chain reaction (PCR) using Taq DNA polymerase (Promega, Madison, Wisconsin). PCR was applied using the thermal profile of $95{ }^{\circ} \mathrm{C}$ denaturation $(45 \mathrm{sec}), 54{ }^{\circ} \mathrm{C}$ annealing $(30 \mathrm{sec})$ and $72{ }^{\circ} \mathrm{C}$ extension $(1 \mathrm{~min})$ for 30 cycles. Double stranded PCR products were purified with by Wizard PCR Preps (Promega, Madison, Wisconsin). The thermal protocol for cycle sequencing (using Gibco-BRL's kit, obtained from Life Technologies, Rocklive, Ma- ryland) was $95^{\circ} \mathrm{C}(30 \mathrm{sec}), 55^{\circ} \mathrm{C}(30 \mathrm{sec})$ and $70{ }^{\circ} \mathrm{C}$ ( $\left.1 \mathrm{~min}\right)$ for 30 cycles, using the conserved primers (L14724a, H15050 and H15400) (Anderson et al. 1981), and the designed primers obtained from MacVector (Accelrys, San Diego, California): forward F78: 5'-TCCAATGTAGGAATTATGACCCACC-3'; Reverse B 149: 5' -TTTCCCATCTCTGGCTTACAAGAC-3'. Radiolabeled sequencing products were resolved by vertical acrylamide electrophoresis and visualized by autoradiography; most of the sequencing reactions were analyzed 
in an ABi Prism 310 automated sequencer, labeling primers with the Big Dye Terminator kit of Perkin Elmer (Foster City, California).

\section{Data analysis}

Sequences were aligned through ClustalX (Thompson et al. 1997) using default values, and then proofed by eye. Frequencies of nucleotide bases and compositional biases were estimated using MEGA2 (Kumar et al. 1993) and PAUP*4.0b8a (Swofford 2002). Homogeneity among taxa was tested using chi-square tests of contingency tables of nucleotide counts, as implemented in MEGA2. Number of transitions, transversions, and changes per codon position were counted through the program MacClade 3.0 (Maddison \& Maddison 1992). PAUP*4.0b8a was also used to estimate uncorrected (p), Kimura 2 Parameters (K2P) (Kimura 1980), and Hasawaga, Kimura and Yano (HKY) genetic distances (Hasegawa et al. 1985), and to generate phylogenetic reconstructions. All characters were analyzed as unordered, except for converted amino acid sequences. The Dolichotis patagonum sequence was assigned as the outgroup.

Maximum-parsimony (MP) analyses were conducted using PAUP*4.0b8a (Swofford 2002). The branch-and-bound option was used to identify the most parsimonious tree(s). Heuristic bootstrap analysis with 1,000 replicates were run, and Bremer decay indexes (AutoDecay 4.0) (Eriksonn 1999) were calculated to estimate branch support. Character state optimizations were examined with the ACCTRAN and DECCTRAN options.

Maximum likelihood (ML) analyses were implemented in PAUP* 4.0b8a (Swofford 2002). The MP tree was used for selection of a model of DNA evolution that best fits the data for likelihood analysis, assessing likelihood scores for a nested array of 56 models included in MODELTEST (Posada \& Crandall 1998). The HKY+G model generated significantly better likelihood scores; therefore this model was used to perform heuristic searches with the tree-bisection-reconnection (TBR) branch swapping, and bootstrap analysis.

\section{RESULTS}

We obtained a 1,125-1,140 bp sequence for almost all the mitochondrial cytochrome $b$ gene. Additionally, we examined short sequences (490-678 bp) from two domestic guinea pigs and eight wild ones. All sequences were similar in base composition (chi-square test; $\mathrm{P}=1.00$, $\mathrm{df}=45)$. Average base compositions were $\mathrm{A}=$ $27.8 \%, \mathrm{C}=30.4 \%, \mathrm{G}=14.3 \%$, and $\mathrm{T}=27.4$ $\%$, with significant compositional biases at the second $(\mathrm{G}=14.1 \%)$ and third $(\mathrm{G}=6.2 \%)$ codon positions.

Maximum-parsimony analysis detected 325 parsimony-informative characters and generated 120 equally parsimonious trees, with no significant differences among them (KishinoHasegawa test as implemented in PAUP). All had lengths of 609 steps, much shorter than any of the 1,000 trees randomly generated by the same matrix (mean length $=1,491$ steps, $\mathrm{SD}=$ 88.29 and $\mathrm{g} 1=-1.29)$, indicating the strong phylogenetic signal conveyed by this data set. The consensus MP tree (Fig. 1) had a Consistency Index (CI) of 0.80 , a Retention Index (RI) of 0.89 and a Rescaled Index (RC) of 0.71. All nodes, excluding node $\mathrm{i}$, had high bootstrap and Support Index values (numbers above and below branches in Fig. 1); these included the $C$. porcellus lineage (node g, based on 15 unambiguous substitutions after optimization under ACCTRAN and DECCTRAN results) and its link to $C$. tschudii (node $\mathrm{f}$, based on 23 unambiguous substitutions). The alternative tree forced to join $C$. aperea and $C$. porcellus had 23 additional steps, $\mathrm{CI}=0.77, \mathrm{RI}=0.87, \mathrm{RC}=0.67$, with only a single substitution supporting such hypothetical node. Similar results were obtained by further MP analysis adding short sequences from other specimens (Table 1).

Maximum-likelihood analysis (-ln L 4419.52, ti: $\mathrm{tv}$ ratio $=2.072276$, gamma shape $=$ 0.3009 ) produced the same topology as in the MP tree, excepting the node $\mathrm{i}$ with the lowest support (Fig. 2) and the new node k that grouped Microcavia and Cavia sequences. Bootstrap values (500 replicates) were also high, including those of the $C$. porcellus lineage (node g), its union to $C$. tschudii (node f), and to a particular South American domestic lineage (node h) from southern Peru and northern Chile. Forcing $C$. aperea to be the sister node of $C$. porcellus produced a significantly less likely topology (-ln L $=$ 4446.54; Kishino-Hasegawa test; $\mathrm{P}<0.01$ ). Further analysis of specimens with short sequences (not shown) placed the Peruvian specimen from Arequipa within node $\mathrm{h}$.

Mean generalized " $p$ " and K2P distances between the sequences of $C$. tschudii and $C$. aperea were $7.2 \%$ (range 6.8-7.6) and $7.7 \%$ respectively. When $C$. aperea and $C$. porcellus sequences were compared, these statistics reached $7.9 \%$ (range 7.2-8.5) and $8.5 \%$ respectively. By contrast, the mean distance values between $C$. tschudii and $C$. porcellus sequences were $3.1 \%$ (range $2.7-3.3$ ) and $3.2 \%$. 


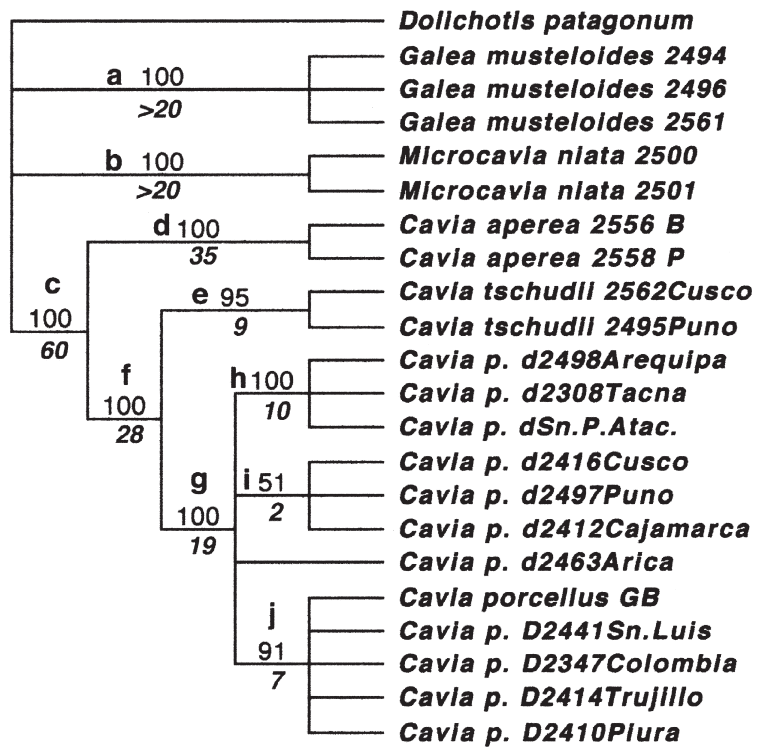

Fig. 1: Consensus, most parsimonious tree from equally weighted MP analysis of mitochondrial cytochrome b gene sequences. Tree length $=609$ steps, $\mathrm{CI}=0.796, \mathrm{RC}=0.890$. Percent bootstrap support (1,000 replicates) appears above branches; Bremer Decay indices are below (in italics). Lower case letters $(\mathrm{a}-\mathrm{j})$ designate nodes.

Árbol de consenso más parsimonioso a partir del análisis MP de igual peso de las secuencias mitocondriales del gen para citocromo b. Longitud del árbol $=609$ pasos, $\mathrm{CI}=0,796 ; \mathrm{RC}=0,890$. Porcentaje de apoyo en remuestreos (1.000 réplicas) aparecen sobre ramas; índices de apoyo de Bremer aparecen debajo de ramas (en itálicas). Letras minúsculas (a-j) designan nodos.

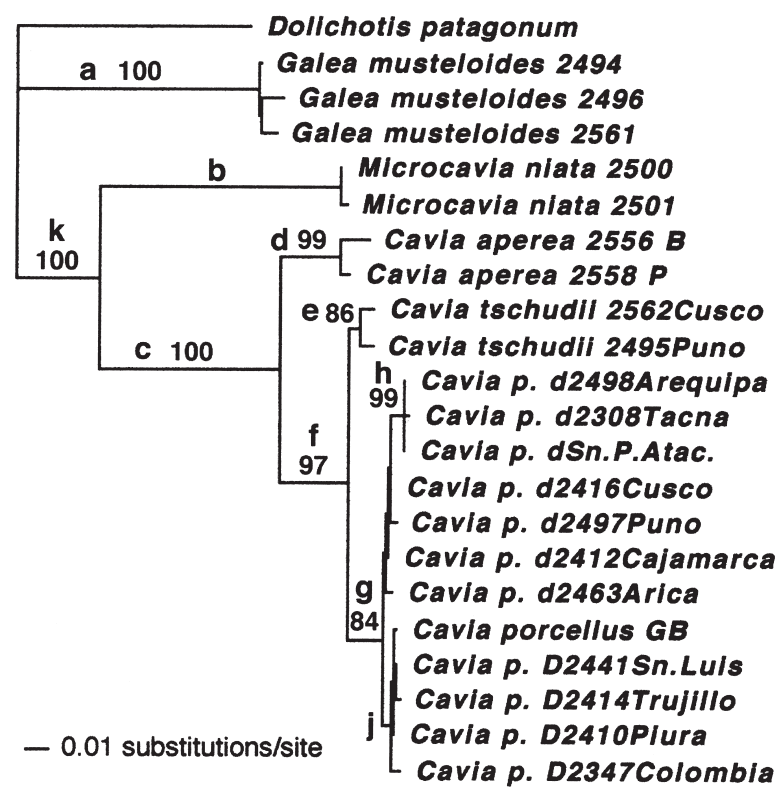

Fig. 2: Maximum likelihood tree $(-\ln \mathrm{L}=4419.52$, ti:tv ratio $=2.072276)$ based on sequences of the cytochrome $\mathrm{b}$ gene. $\mathrm{D}=$ domestic specimen from laboratory, city markets or pet shops; $\mathrm{d}=$ domestic specimen from houses or rural markets. Numbers after taxonomic names are LCM collection numbers. Bootstrap values (1,000 replicates; $>50 \%)$ are over each node. Abbreviations as in Fig. 1.

Árbol de máxima verosimilitud (- ln $\mathrm{L}=4419,12$, proporción ti:tv $=2,072276$ ) basado en las secuencias del gen para citocromo b. D = especímen de laboratorio, mercados citadinos, o tiendas de mascotas; $\mathrm{d}$ = especímen doméstico de casas o mercados rurales. Números después de nombres taxonómicos son de la colección LCM. Valores de remuestreo (1.000 réplicas; $>50 \%$ ) están sobre cada nodo. Abreviaturas como en Fig. 1. 
Non-silent substitutions were analyzed by transforming the total evidence matrix for this coding gene into amino acid sequences. A total of 380 characters resulted, of which 51 were parsimony-informative. The resulting twelve MP trees had 779 steps in length, with $\mathrm{CI}=0.802$ and $\mathrm{RC}=0.721$, with no significant differences among them (Kishino-Hasegawa tests). The strict consensus tree then computed had a $\mathrm{CI}=$ 0.80 . When $C$. aperea was forced to join $C$. porcellus, the resulting tree had 23 additional steps $(\mathrm{CI}=0.76)$, with no amino acids shared by members of this hypothetical node.

Most nodes of the amino acid-based consensus MP tree (Fig. 3) had high bootstrap supports. Node f grouped $C$. tschudii with $C$. porcellus again, defined by three derived amino acid substitutions. Although node g had weak support, it was defined by a single derived substitution. Node h with three South American domestic guinea pigs appeared once again with high support, diagnosed by two derived amino acids (Fig. 3).

\section{DISCUSSION}

A close relationship of domestic guinea pig sequences with those of the wild $C$. tschudii emerges from this molecular analysis. Generalized and K2P molecular distances between domestic guinea pigs and C. tschudii were less than half of that with $C$. aperea. MP and ML analyses grouped them in the monophyletic node f (Fig. 1 and 2). Certainly, the clade $C$. tschudii- $C$. porcellus can be diagnosed by three synapomorphic non-silent substitutions (Fig. 3). When C. aperea was forced to join the C. porcellus, the resulting trees were consistently longer, less likely, and less supported. Therefore, $C$. porcellus probably descends from the lineage leading to $C$. tschudii inhabiting southwestern South America. This idea is consistent with the persistent archaelogical records at different sites (Sandweiss \& Wing 1997) in the same sub-region (Marcus et al. 1999).

Whether $C$. tschudii and $C$. aperea are distinct species (Cabrera 1953) or a single taxon

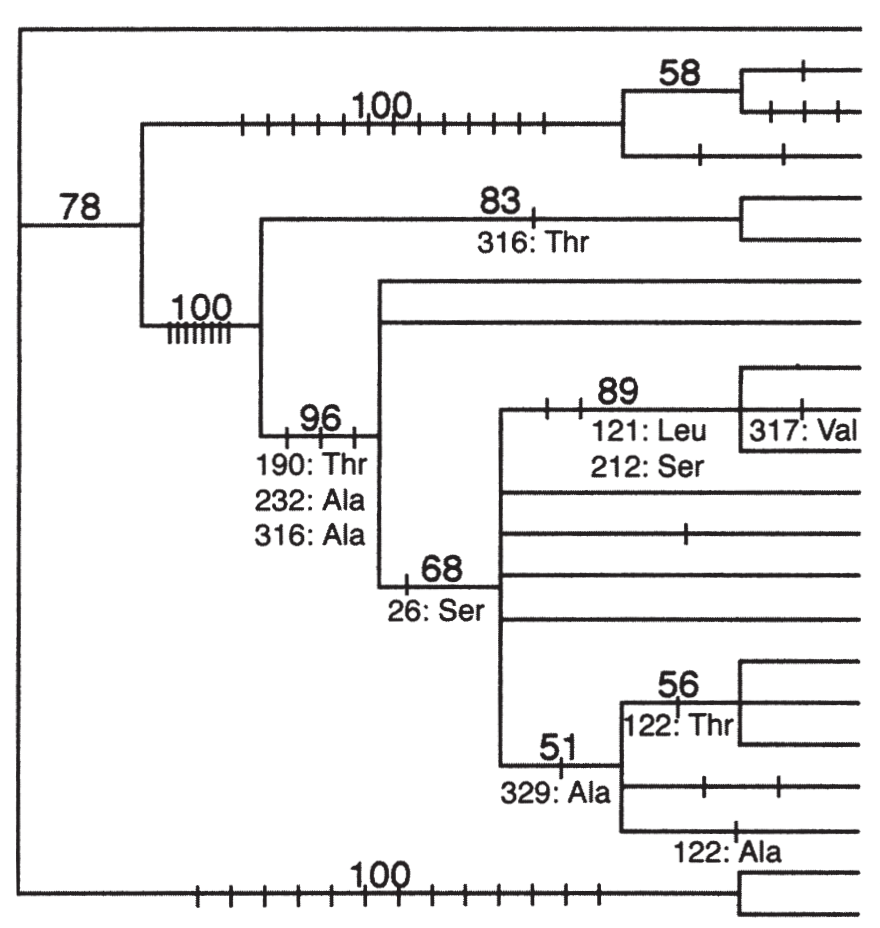

Dolichotls patagonum Galea musteloides 2494 Galea musteloldes 2496 Galea musteloldes 2561 Cavia aperea 2556 B Cavia aperea $2558 \mathrm{P}$ Cavia tschudil 2562Cusco Cavia tschudil 2495Puno Cavla p. d2498A requipa Cavia p. d2308Tacna Cavia p. dSn.P.Atac. Cavia p. d2416Cusco Cavia p. d2497Puno Cavia p. d2412Cajamarca Cavia p. d2463Arica Cavia porcellus GB Cavia p. D2441Sn.Luls Cavia p. D2410Plura Cavia p. D2347Colombia Cavia p. D2414Trujillo Microcavia niata 2500 Microcavia niata 2501

Fig. 3: Consensus MP tree based on the inferred 380 amino acids of cytochrome b (51 were informative). Tree length $=779$ steps, $\mathrm{CI}=0.802$ and $\mathrm{RC}=0.72$. Dolichotis sequence was designated as the outgroup; characters were ordered accordingly. Bootstrap values $(1,000$ replicates; $>50$ $\%)$ over each branch. Site number below, followed by the shared amino acid substitution.

Árbol MP de consenso basado en 380 aminoácidos inferidos del citocromo b (51 fueron informativos). Longitud del árbol $=779$ pasos, $\mathrm{CI}=0,802$, y RC $=0,72$. La secuencia de Dolichotis fue designada como grupo externo; los caracteres fueron consecuentemente ordenados. Valores de remuestreo (1.000 réplicas; > $50 \%)$ sobre cada rama. Número del sitio debajo, seguido por la sustitución aminoacídica compartida. 
(Huckinghaus 1961), as suggested by their interfertilization, remains an unsettled issue. $\mathrm{Ne}$ vertheless, the genetic distance between them $(7.7 \%)$ is more consistent with their distinction. It has been recently stated that for mammals, K2P genetic distances based on cytochrome b gene with "values between $2 \%$ and $11 \%$ had a high probability of being indicative of conspecific populations or valid species, and merit additional studies concerning specific status" (Bradley \& Baker 2001). Moreover, the lowest distance value between $C$. tschudii and $C$. aperea involved the single Paraguayan specimen of the latter, and not the geographicallyadjacent Bolivian one. Further sequencing of Bolivian and western Paraguayan samples would help to clarify this issue.

All domestic guinea pig sequences tend to cluster in a single lineage (node g; Fig. 1 and 2). $C$. porcellus can now be recognized by the synapomorphic condition of the amino acid serine at site 26 (Fig. 3). This is in accordance with the morphological (Cabrera 1953), physiological and behavioral (Wagner \& Manning 1976) traits they all seem to share. Therefore, it seems that all guinea pigs probably had a recent common ancestor around the sixteenth century, when animals were shipped to Europe for the first time (Wagner \& Manning 1976). Sampling from other European countries, United States and South America could provide additional support for the monophyletic origin of C. porcellus.

The $C$. porcellus now found throughout South America did not form a monophyletic group in our molecular analysis. In fact, Peruvian guinea-pig breeders (Chauca 1997) differentiate the prolific, large-sized cuyes exhibiting a calm behavior (called "mejorados" = improved), from the small-sized, nervous ones (the "criollos" = creoles), typically found in rural houses (Archetti 1997). Indeed, our molecular analyses suggest that "mejorados" share a most recent common ancestor with the European guinea pig (node j in Fig. 1 and 2) that is not the ancestor of creoles. This idea should be tested with other molecular markers in wider samples.

On the other hand, all "criollo" sequences (marked d in Table 1 and figures) never clustered with the "mejorado" lineage, nor formed a group by themselves except in a low supported node of the ML tree (Fig. 2). This lack of cohesiveness parallels the higher molecular diversity within this group of "criollos" $(\mathrm{d}=7.333, \mathrm{SE}$ $=1.840$ ) when compared to that of the "mejorados" $(\mathrm{d}=3.600, \mathrm{SE}=1.290)$. Such high diversity is probably the expression of a long history of divergence among "criollos" which is cohe- rent with the archeological (Sandweiss \& Wing 1997) and historical records of Cavia in the area (Marcus et al. 1999) as well as with the breeding and social systems traditionally used by Andean rural communities (Archetti 1997).

The particular and highly supported node $\mathrm{h}$ of creole C. porcellus from southern Peru and Chile, uniquely defined by two shared amino acid substitutions (Fig. 3) suggest that this is an old pre-Columbian lineage (Wing 1986, Morales 1995). Further studies on rural communities should uncover other pre-Columbian breeds along the Andes.

\section{ACKNOWLEDGEMENTS}

Our work was supported by FONDECYT, grant 1011052. A FONDECYT Sectorial Project (596 0017) also allowed initial field and laboratory work. We thank the Servicio Agrícola y Ganadero, Chile, and the Corporación Nacional Forestal, Ministerio de Agricultura, Chile, for granting collection permits. We thank J. C. Torres-Mura (Museo Nacional de Historia Natural, Santiago, Chile), E. Lessa (Universidad de la República, Montevideo, Uruguay), and T. Yates (Museum of Southwestern Biology, University of New Mexico, USA) for their generous share of samples, to P. Iturra (Universidad de Chile) for sharing laboratory facilities, and to M. Kunz and J. Oyarce for technical assistance in collecting and care of animals.

\section{LITERATURE CITED}

ANDERSON S, A BANKIER, B BARREL, M DE BRUJIN, A COULSON, J DROUIN, I EPERON, D NIERLICH, B ROE, F SANGER, P SCHREIER, A SMITH, R STADE \& G YOUNG (1981) Sequence and organization of the human mitochondrial genome. Nature 290: 457-465.

ANDERSON S (1997) Mammals of Bolivia, taxonomy and distribution. Bulletin of the American Museum of Natural History (USA) 231: 1-652.

ARCHETTI E (1997) Guinea Pigs: food, symbol and conflicts of knowledge in Ecuador (Global Issues). Berg Pub Limited., New York, New York, USA. $256 \mathrm{pp}$.

BRADLEY RD \& RJ BAKER (2001) A test of the genetic species concept: cytochrome b sequences and mammals. Journal of Mammalogy 82: 960-973.

CABRERA A (1953) Los roedores argentinos de la familia Caviidae. Ministerio de Educación, Facultad de Agronomía y Veterinaria, Universidad de Buenos Aires. 6: 1-93.

CASTLE WE \& S WRIGHT (1916) Studies of inheritance in guinea pigs and rats. Carnegie Institution of Washington (USA) 241: 1-192.

CHAUCA L (1997) Producción de cuyes (Cavia porcellus). Food Agricultural Organization Monographs (Italy) 138: 1-77. 
CLUTTON-BROCK J (1999) A natural history of domesticated mammals. Cambridge University Press, London, United Kingdom. 238 pp.

DETLEFSEN JA (1914) Genetic studies on a cavy species cross. Publications of the Carnegie Institution (USA) 205: 1-134.

ERIKSONN T (1999) AUTODECAY 4.0 (program distributed by the author). Bergius Foundation, Royal Swedish Academy of Sciences, Stockholm, Sweden.

HASEGAWA M, J KISHINO \& T YANO (1985) Dating of the human-ape split by a molecular clock of mitochondrial DNA. Journal of Molecular Evolution 21: 160-174.

HUCKINGHAUS F (1961) Vergleichende Untersuchungen uber die Formenmannigfaltigkeit der Unterfamilie der Caviinae Murray 1886. Zeitschrift für Wissenschaftliche Zoologie 166: 1-98.

KIMURA M (1980) A simple method for estimating evolutionary rates of base substitutions through comparative studies of nucleotide sequences. Journal of Molecular Evolution 16: 111-120.

KUMAR S, K TAMURA \& M NEI (1993) MEGA: Molecular Evolutionary Genetics Analysis 1.01. Pennsylvania State University, University Park, Pennsylvania, USA

MADDISON WP \& DR MADDISON (1992) MACCLADE: analysis of phylogeny and character evolution, 3.0. Sinauer Associates, Sunderland, Massachusetts, USA. 398 pp

MANIATIS T, EF FRITSCH \& J SAMBROCK (1992) Molecular cloning. A laboratory manual. Cold Spring Harbour Laboratory Press, Cold Spring Harbour, New York, USA. 1129 pp.

MARCUS J, JD SOMMER \& CP GLEW (1999) Fish and mammals in the economy of an ancient Peruvian kingdom. Proceedings of the National Academy of Sciences USA 96: 6564-6570.

MORALES E (1995) The guinea pig. Healing, food, and ritual in the Andes. The University of Arizona Press, Tucson, Arizona, USA. 177 pp.

NEEDBAL M, M ALLARD \& R HONEYCUTT (1994) Molecular systematics of Hystricognath rodents: evidence from the mitochondrial $12 \mathrm{~S}$ rRNA gene. Molecular Phylogenetics and Evolution. 3: 206-220.

NOMENCLATURE ICOZ (2003) Opinion 2027. Usage of 17 specific names based on wild species which are pre-dated by or contemporary with those based on domestic animals (Lepidoptera, Osteichthyes, Mammalia): conserved. Bulletin of Zoological Nomenclature 60: 81-84.

PICTET A \& A FERRERO (1951) La descendance d'un croisement interspecifique de cobayes (Cavia aperea D'Az x Cavia cobaya Marc) analysee durant 25 annees. Genetica 25: 357-515.

POSADA D \& KA CRANDALL (1998) Modeltest: testing the model of DNA substitution. Bioinformatics 14: $817-818$

ROOD J (1972) Ecological and behavioural comparisons of three genera of Argentine cavies. Animal Behaviour Monographs 5: 1-83.

ROWE DL \& RL HONEYCUTT (2002) Phylogenetic relationships, ecological correlates, and molecular evolution within the Cavioidea (Mammalia, Rodentia). Molecular Biology and Evolution 19: 263-277.

SACHSER N (1998) Of domestic and wild guinea pigs: studies in sociophysiology, domestication, and social evolution. Naturwissenschaften 85: 307-317.

SANDWEISS DH \& ES WING 1997 Ritual rodents: the guinea pigs of Chincha, Peru. Journal of Field Archaeology 24: 47-58.

SWOFFORD D (2002) PAUP* (Phylogenetic Analysis Using Parsimony). Sinauer Associates, Sunderland, Massachusetts, USA.

THOMPSON JD, DG HIGGINS \& TJ GIBSON (1997) The ClustalX-Windows interface: flexible strategies for multiple sequence alignement aided by quality analysis tools. Nucleic Acids Research 25: 4876-4882.

WAGNER JE \& PJ MANNING (1976) The biology of the guinea pig. Academic Press, New York, New York, USA. 317 pp.

WEIR BJ (1974) Notes on the origin of the domestic guinea-pig. Symposia of the Zoological Society of London 34: 437-446.

WING E (1986) Domestication of Andean mammals. In: Vuilleumier F \& M Monasterio (eds) High altitude tropical biogeography: 246-264. Oxford University Press, Oxford, United Kingdom.

WOODS C (1993) Suborder Hystricognathi. In: Wilson DE \& DM Reeder (eds) Mammal species of the world: a taxonomic and geographic reference: 771806. Smithsonian Institution Press, Washington, District of Columbia, USA. 